\title{
Desertification alters the response of vegetation to changes in precipitation
}

\author{
Santiago R. Verón ${ }^{1 *}$ and José M. Paruelo ${ }^{2}$ \\ ${ }^{1}$ Instituto de Clima y Agua, Instituto Nacional de Tecnología Agropecuaria (INTA) \& CONICET. Las Cabañas y Los \\ Reseros s/n, Buenos Aires, Argentina; ${ }^{2}$ Laboratorio de Análisis Regional y Teledetección, IFEVA-Depto Métodos \\ Cuantitativos y Sistemas de Información, Facultad de Agronomía, Universidad de Buenos Aires and CONICET, Av. \\ San Martín 4453, C1417DSE, Buenos Aires, Argentina
}

\begin{abstract}
Summary
1. Desertification is of critical concern because it may affect $40 \%$ of the global land area inhabited by more than 1 billion people. During the process of desertification, defined as land degradation in arid, semi-arid and dry subhumid areas, drylands shift to a state of reduced biological productivity that may lead to widespread loss of human well-being. Despite recent advances, we need a better understanding of the response of ecosystems to desertification to improve the assessment and monitoring of desertification.
\end{abstract}

2. We used a published physiognomic description, MODIS monthly NDVI data for 2000-2005 and rain gauge data to characterize the long-term effects of degradation for an area of 128000 ha located in western Patagonia.

3. We focused on three aspects of vegetation dynamics: radiation interception, precipitation use efficiency (PUE) and the sensitivity of vegetation to interannual changes in precipitation (i.e. the slope of the relationship between the above-ground net primary productivity and precipitation, the precipitation marginal response, PMR). In particular, we analysed the response of PMR and PUE to long-term changes in vegetation structure due to grazing.

4. On average, NDVI decreased by $28 \%$, ranging between $35 \%$ (grass or grass-shrub steppes to semi-deserts) and $22 \%$ (grass or grass-shrub steppes to low cover grass steppes) suggesting that, in Patagonia, desertification may imply a reduction in the above-ground net primary productivity.

5. Additionally, PMR and PUE captured the functional modifications associated with vegetation structure caused by desertification. In general, grass and grass-shrub steppes had the highest average PUE and PMR. Shrub steppes and semi-deserts had the lowest PMR and PUE. These results support the hypothesis that PUE is more sensitive to changes in total plant cover and PMR to changes in plant functional type composition.

6. Synthesis and applications. Our results indicate that the precipitation marginal response could complement current desertification assessments based only on precipitation use efficiency thereby improving our ability to monitor desertification. Enhanced monitoring programmes could provide an early warning signal for the onset of desertification allowing for timely management action.

Key-words: grazing, land degradation, NDVI, Patagonia, precipitation marginal response, precipitation use efficiency

\section{Introduction}

Land degradation in arid, semi-arid and dry sub-humid areas is a frequent feature of dryland ecosystems and often manifests itself as a consequence of grazing management, wood collection and cultivation (Reynolds 2001). Stopping and/or

*Correspondence author. E-mail: sveron@cnia.inta.gov.ar reversing this process is crucial because areas subjected to desertification cover more than $40 \%$ of the global land area and are inhabited by more than 1 billion people. Despite recent advances, a better understanding of the response of ecosystems to desertification is needed to reduce the uncertainties regarding the extent of the area affected, the temporal dynamics of desertified or desertification-prone areas and the relative importance of biophysical and socioeconomic drivers (Maestre \& Escudero 2009) 
Desertification is believed to involve ecosystem functional and structural changes such as increased runoff (Sharma 1998), decreased secondary production (Hill, Megier \& Mehl 1995), increased landscape and soil resources heterogeneity (Schlesinger et al. 1990; Hanafi \& Jauffret 2008) and physiognomic changes (e.g. replacement of grasslands by shrublands) (Huenneke et al. 2002). The above-ground net primary productivity (ANPP, the rate of net carbon accumulation by vegetation in above-ground organs) has been used as an indicator of desertification because it correlates with key aspects of ecosystem functioning like herbivore biomass, consumption and secondary productivity (McNaughton et al. 1989). However, the use of ANPP has been hampered by the association between ANPP and precipitation, which, in drylands, is highly variable between years (Noy-Meir 1973). Recent evidence suggests that ANPP is extremely heterogeneous both temporally and spatially, even among contrasting physiognomies (Huenneke et al. 2002). While the interannual variability of ANPP as a consequence of changing precipitation could be ruled out by using the precipitation use efficiency as an indicator (see below), the question of whether ANPP decreases or not with desertification remains open and central to the study of the desertification process.

The precipitation use efficiency is the ratio of annual ANPP to annual precipitation, PUE (Le Houérou 1984). By normalizing ANPP by precipitation PUE accounts for the interannual variability in precipitation rendering a more stable and interpretable indicator of desertification than ANPP. Although originally named rain use efficiency we prefer PUE because plants use water provided not only by rainfall but also by other types of precipitation such as snowfall and, additionally, because it avoids confusion with radiation use efficiency. PUE has been used as an indicator of desertification over extensive areas of the African Sahel (Nicholson, Tucker \& Ba 1998; Prince, Brown de Colstoun \& Kravitz 1998; Diouf \& Lambin 2001), Australia (Holm, Cridland \& Roderick 2003), and South Africa (Wessels et al. 2007) based on the assumption that land degradation reduces vegetation productivity due to, among others, soil erosion, an increase in surface runoff and changes in vegetation composition without altering, at least initially, precipitation regimes (Wessels et al. 2007). However, recent findings suggest that PUE may not be a good indicator of desertification because of (i) extreme ANPP heterogeneity (Huenneke et al. 2002) and (ii) variation among years in PUE: in wet years following dry years PUE is low while the opposite occurs in dry after wet years (Prince, Brown de Colstoun \& Kravitz 1998; O’Connor, Haines \& Snyman 2001; Hein \& de Ridder 2006; Prince et al. 2007; Wessels et al. 2007).

A variable that has been proposed as a useful complement to PUE in desertification assessments is the precipitation marginal response (Verón, Paruelo \& Oesterheld 2006). It is defined as the slope of the linear relationship between annual ANPP and annual precipitation (PMR, Verón, Oesterheld \& Paruelo 2005). Although PUE and PMR relate the same two key aspects of dryland ecosystems - ANPP and precipitation and their definitions have been frequently confused (Verón, Oesterheld \& Paruelo 2005), they provide different information about ecosystems' properties. As a ratio, PUE indicates the amount of ANPP produced by each millimeter of annual precipitation per unit area while, as a slope of a linear relationship, PMR describes the sensitivity of ANPP to interannual changes in precipitation. PMR could thus avoid the artefact of PUE tending to infinity when precipitation tends to zero; it could still provide valuable information when changes in ANPP due to desertification are small or non-existent (Verón, Paruelo \& Oesterheld 2006). The use of PMR in desertification studies is based on results from studies that compared ANPP and precipitation from degraded and non-degraded sites over several years (O'Connor, Haines \& Snyman 2001; Huenneke et al. 2002).

It is difficult to determine the desertification status of a piece of land because of the need for a reference situation to which the actual situation could be compared (Verón, Paruelo \& Oesterheld 2006; Prince et al. 2007) and the lack of adequate ANPP datasets (Scurlock, Johnson \& Olson 2002). We overcame these shortcomings by identifying a reference situation based on the Paruelo (2005) hypothesis (see next section) and by using a remotely sensed surrogate of ANPP, the normalized vegetation differential index (NDVI) which has been extensively used in desertification studies (e.g. Nicholson, Tucker \& Ba 1998; Prince, Brown de Colstoun \& Kravitz 1998).

The specific objectives of this study are (i) to evaluate changes in ANPP (assessed from NDVI data) associated with the degradation processes and (ii) to analyse the response of PMR and PUE to changes in vegetation structure associated with desertification. The hypothesis underlying our study is that PUE will be more sensitive to changes in total plant cover because cover is a key determinant of the fraction of precipitated water captured by plants, and PMR will be more sensitive to changes in plant functional type composition because functional types group attributes that characterize the response of vegetation to environmental fluctuations. We predict that when desertification translates into the replacement of grasslands by shrublands the decrease in PMR will be more noticeable than in PUE while the opposite will occur when soil cover is reduced without physiognomic modifications.

The study area encompasses almost 128000 ha located in the Sub-Andean district of Patagonia whose degradation pattern and spatial distribution were analysed and described by Paruelo (2005) based on a detailed mapping of vegetation (Paruelo et al. 2004). We compared PMR and PUE, calculated from 5 years of satellite and precipitation data, from (i) physiognomies characteristic of different degradation status and (ii) from similar physiognomies located at paddocks with different herbivore consumption.

\section{IDENTIFICATION OF THE REFERENCE SITUATION}

The selection of the study area is based on evidence that allows us to identify the vegetation of the non-degraded state (Paruelo 2005; see Appendix S1, Supporting Information). This evidence derives from state and transitions models (Paruelo \& Bertiller 1993; Bertiller \& Bisigato 1998), studies describing grazing impacts on Sub-Andean district vegetation (León \& 
Aguiar 1985) and floristic relevés (Bertiller et al. 1995; Paruelo et al. 2004). Sheep grazing started in Patagonia during the first two decades of the 20th century (Soriano \& Paruelo 1990).

Paruelo (2005) presented a synthesis of available state and transition models for Festuca grasslands of the Sub-Andean district adapted to the desertification context. The model depicts a sequence of three states (Fig. 1). The first state belongs to the slight or non-degraded situation described by Golluscio, León \& Perelman (1982) as homogeneous herbaceous steppes with $64 \%$ of vegetation cover comprised mainly by Festuca pallescens among grasses (93\% relative cover) and Mulinum spinosum among shrubs (though with low fidelity) (state 1). In phytosociological terms it has been characterized as the Festuca pallescens, Rhytidosperma picta and Lathyrus magellanicus community. As degradation progresses, bare soil cover increases with the concomitant decrease of plant cover and in particular grasses (state 2). Grazing can change vegetation physiognomy (León \& Aguiar 1985; Soriano \& Movia 1986; Bertiller 1996) and transform the grass steppes into a shrub steppe or even a semi-desert with a soil cover of less than $25 \%$. Once soil is denuded, erosion due to water or wind increases thereby diminishing the superficial soil layer and hindering the establishment of new propagules (state 3). Taken together, these observations support the increasing degradation sequence wherein the former grass or grass-shrub steppes, characteristic of slight or non- degraded situations, are transformed into low covered grass steppes, shrub steppes or semideserts. It is important to notice that the state defined corresponded to a continuum of physiognomic change.

In the study area Paruelo et al. (2004) found that despite wide variability in physiognomies, as assessed by means of floristic relevés and remote sensing, its floristic composition was quite similar. This meant that in sites with contrasting physiognomies such as semi-deserts and grass steppes, the species composition was alike. Thus, a set of species characteristic of the pristine community that still persists at reduced abundance in the degraded community is termed the "original vegetation memory' effect.

Based on the hypothesis of the 'floristic memory' of the system and an extensive set of relevés, Paruelo (2005) identified an area whose original vegetation would correspond to the Festuca pallescens, Rhytidosperma picta and Lathyrus magellanicus community described by Golluscio, León \& Perelman (1982) (see Appendix S1) and this constituted our study area.
The delimitation of its boundaries was based on the inclusion of sites where species characteristic of this community would be present (Table 1), Festuca pallescens would be dominant and Stipa speciosa cover was less than $1 \%$. Thus, the 128000 ha delimited by Paruelo (2005) and used in this study corresponds to a smaller area than the one inspected so as to reduce any uncertainty regarding the exact location of its limits.

\section{Materials and methods}

\section{STUDY AREA}

The study area is located in western Patagonia, between $70.9^{\circ}$ and $71.45^{\circ} \mathrm{W}$ and $43.7^{\circ}$ and $44.25^{\circ} \mathrm{S}$ (Fig. 2). Soils mainly belong to the Molisol and Inceptisol orders (Golluscio, León \& Perelman 1982) and the topography is gently rolling because of glacier action. The area corresponds to the Patagonian phytogeographical province of the Sub-Andean district (Soriano 1956) physiognomically characterized as a high cover grass steppe (León et al. 1998).

Mean annual temperature was $7 \cdot 9^{\circ} \mathrm{C}$, July was the coldest month $\left(1.3^{\circ} \mathrm{C}\right)$ and January the warmest $\left(13 \cdot 5^{\circ} \mathrm{C}\right)$. Mean annual precipitation for the last 24 years was $505 \mathrm{~mm}, 74 \%$ as rainfall and the rest as snow. Even though a steep west-east precipitation gradient has been

Table 1. Key species used by Paruelo (2005) to identify the area whose original vegetation would correspond to the Festuca pallescens, Rytidosperma picta and Lathyrus magellanicus community

\begin{tabular}{ll}
\hline $\begin{array}{l}\text { Evergreen low shrubs } \\
\text { Nassavia juniperina }\end{array}$ & $\begin{array}{l}\text { Annual herbs } \\
\text { Gassauvia darwinii } \\
\text { Senecio sericionitens }\end{array}$ \\
Taraxacum officinale \\
Mesofitic perennial grasses & $\begin{array}{l}\text { Perennial herbs (leaf shedding) } \\
\text { Rumex acetosella } \\
\text { Deschampsia flexuosa }\end{array}$ \\
Elymus patagonicus & Vicia biyuga nivalis \\
Festuca pyrogea & Erigeron cinereus \\
Koeleria grisebachii & Evergreen perennial herbs \\
Koeleria sp. & Armeria maritima \\
Rhytidosperma picta & Astragalus sp. \\
& Fragaria chiloensis \\
Xerofitic perennial grasses & Hypericum punctatum \\
Festuca pallescens & Lathyrus magellanicus \\
& Trifolium repens \\
Chlorera sp.
\end{tabular}

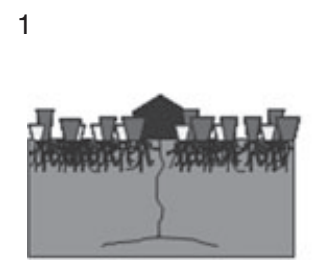

Grass or grass-shrub steppes

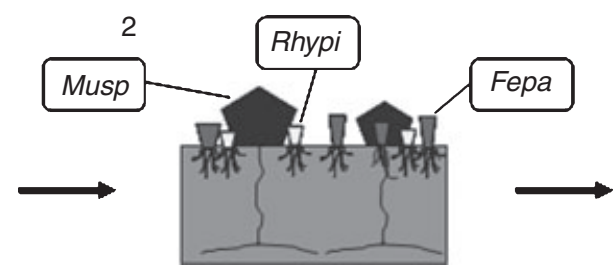

Low cover grass steppes or shrub steppes
3

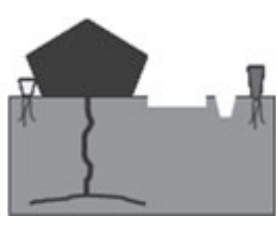

Semideserts

Fig. 1. State and transition scheme for the Festuca pallescens grasslands of the Sub-Andean district. Numbers refer to increasing degradation states. Musp stands for the deciduous shrub Mulinum spinosum, Rhypi for the mesophytic perennial grass Rhytidosperma picta and Fepa for the perennial grass Festuca pallescens. Adapted from Paruelo (2005). 


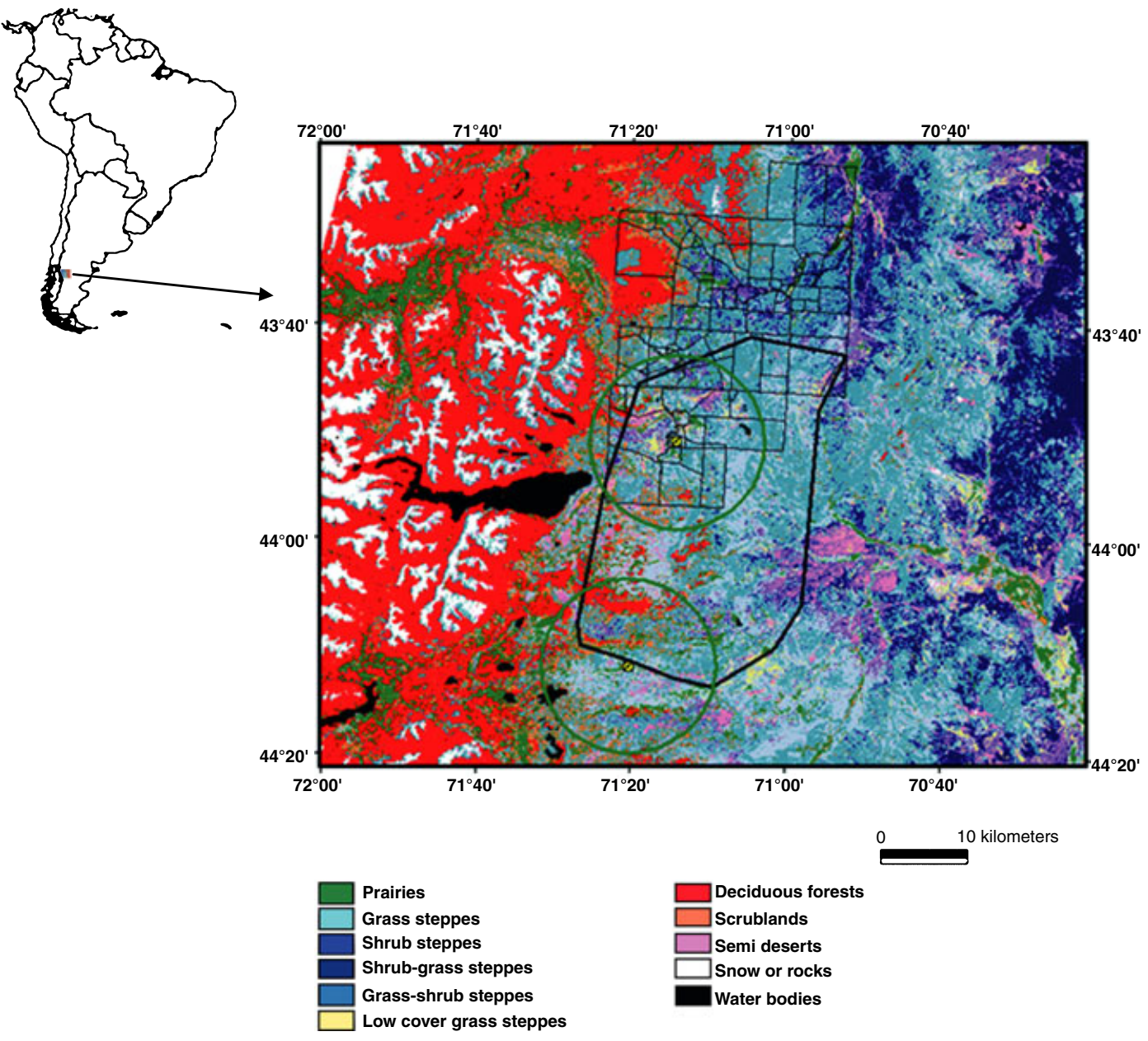

Fig. 2. Study area. Over imposed to the physiognomic classes classified by Paruelo et al. (2004) is the polygon (black filled line) defined by Paruelo (2005) whose original vegetation would belong to the F. pallescens, R. picta and L. magellanicus community described by Golluscio, León \& Perelman (1982). Thin black lines represent the paddocks of the Estancia Tecka ranch. Yellow dots indicate the location where precipitation was registered. Only pixels situated within the polygon and no further than $15 \mathrm{~km}$ from the yellow dots - marked by a green circle - were used.

described in this district, we could not find differences in mean annual precipitation for the study period between 2 sites located approximately at the same latitude but $16 \mathrm{~km}$ apart longitudinally (469 and $438 \mathrm{~mm}$, paired difference test $n=7, t=1 \cdot 59)$. More than $73 \%$ of precipitation falls during the cold months of April to September which determines a marked asynchrony between the wet season and the growing season (Paruelo \& Sala 1995).

\section{SATELLITE DATA}

We used the NDVI produced every 16 days by the MODIS sensor on board the TERRA series of satellites. The NDVI is correlated with the proportion of photosynthetic active radiation intercepted by green tissues (e.g. Sellers et al. 1992) and is a direct estimator of ANPP in areas where the seasonal dynamics of NDVI and incoming photosynthetic radiation are correlated (Piñeiro, Oesterheld \& Paruelo 2006), which is the case in Patagonia (Jobbágy, Sala \& Paruelo 2002; Fabricante, Oesterheld \& Paruelo 2009). Previous work in an area that encompassed our study site found a highly significant $\left(r^{2}=0 \cdot 84, P<0 \cdot 001\right)$ relationship between NDVI and ANPP estimated from biomass harvests (Paruelo et al. 2004). Even if a prairie habitat [considered in Paruelo et al. (2004) and excluded from our analysis] is omitted, the NDVI-ANPP relationship is still significant $(P<0.05)$ although NDVI would explain a lesser proportion of the variation in ANPP $\left(r^{2}=0 \cdot 43\right)$. The spatial resolution of this MODIS product (MOD13Q1, Huete et al. 2002) is $250 \mathrm{mts}(6.2 \mathrm{ha})$ and the period analysed extends from September 2000 to July 2005. Low quality data ('utilization index' 7 - average quality - or lower) were discarded. We used the algorithm developed by Viovy, Arino \& Belward (1992) to eliminate remaining artefacts related to cloudy periods or to transmission errors. We thus accepted NDVI reductions during the growing season only when during the following 30 days there was not a value $120 \%$ higher than the lowest immediate value and accepted NDVI increases only when the following NDVI value was less than $150 \%$ of the preceding value. The 'search period' was 30 days which is similar to the one recommended by Viovy, Arino \& Belward (1992). Deleted values were replaced by a linear interpolation between the antecedent and subsequent dates after replacing negative values by zero. In this way we obtained monthly and annual NDVI values for every pixel located within the study area for five growing seasons. The analysis was restricted to the period with available data on NDVI, precipitation and grazing data.

\section{PHYSIOGNOMIC CLASSES}

The proportion of each pixel occupied by each physiognomy was obtained from the classification made by Paruelo et al. (2004). By means of data on total cover and plant functional types 
(i.e. proportion of grasses, shrubs and trees) derived from floristic relevés, these authors performed a supervised classification of Landsat 5 TM reflective bands. From the nine physiognomic classes defined in Paruelo et al. (2004) we were only interested in the steppes and semideserts and only took into account the following classes:

1. Grass steppes (GS): dominated by grasses (Festuca pallescens) and total cover over $40 \%$

2. Grass-shrub steppes (GSS): grass (Festuca pallescens) and shrubs (Mulinum spinosum) co-dominance.

3. Shrub steppes (SS): Grass cover is usually very low. Among shrubs the sub-shrub Nassauvia glomerulosa dominates.

4. Low cover grass steppes (LCGS): this class is a degraded condition of the Festuca pallescens grass steppe. The sub-shrub Azorella sp. is usually present.

5. Semi-deserts (SD): total cover is less than $30 \%$ and low, cushionlike, shrubs dominate (Nassauvia glomerulosa, Acaena splendens, Verbena sp. o Azorella monantha).

The information on physiognomic classes was aggregated to match the $250 \times 250 \mathrm{~m}$ scale of the MODIS data. The proportion of each physiognomic class present in each $250 \times 250 \mathrm{~m}$ cell was calculated with ESRI ArcView 3.3 GIS software. We discarded 'azonal' pixels, e.g. those having more than $1 \%$ of rock, snow, water bodies, forests, scrublands and prairies cover. Nothofagus forests and scrublands were not considered because these are vegetation types characteristic from the Sub-Antarctic phytogeographical province. The prairies exclusion was based on the assumption that the considerable subsuperficial water additions they receive makes precipitation a poor estimator of water availability. Thus, based on the Paruelo (2005) state and transition model we assumed that the original vegetation of the remaining pixels (previous to sheep grazing introduction) corresponded to the Festuca pallescens, Rhytidosperma picta and Lathyrus magellanicus community defined by Golluscio, León \& Perelman (1982) and that the physiognomic heterogeneity is a consequence of the desertification process

\section{PRECIPITATION}

We compiled daily precipitation data from two sites located within or less than $2 \mathrm{~km}$ from the study area (Fig. 2) for a longer period than the NDVI data. Only pixels situated within $15 \mathrm{~km}$ from the meteorological stations were used in order to assure a precipitation value representative of the real situation. It was assumed that $1 \mathrm{~cm}$ of snow equals $1 \mathrm{~mm}$ rain (Akinremi, McGinn \& Cutforth 1999).

For the Sub-Andean district, Paruelo, Jobbagy \& Sala (1998) and Jobbágy, Sala \& Paruelo (2002) showed that thermal constraints restricted the growing season, on average, from October to mid-April though the end of the growing season may occur earlier depending on water availability. Water availability during the growing season included the water stored in the soil profile during winter plus the growing season precipitation. The portion of winter precipitation exceeding the soil water retention capacity will runoff or drain (Paruelo, Sala \& Beltrán 2000) and thus will not be available for plants. As a consequence of the marked winter precipitation regime, water availability at the beginning of the growing season is equal to the soil water storage in most years. Thus, for a discrete time period as considered here, annual precipitation may not be an adequate estimator of water availability experienced by the vegetation.

Considering the particular characteristics of water dynamics in the area, we calculated PMR using the NDVI and precipitation from the growing season (October to March). PUE was calculated as the ratio between growing season NDVI and precipitation both averaged over the study period. We multiplied by 10000 to change the scale of PMR and PUE.

\section{DATA ANALYSES}

In spatially structured datasets such as the one employed here, spatial and temporal autocorrelation may violate the assumptions of independency and homogeneity of variance impairing statistical significance tests. To avoid this, we used a linear mixed model by means of the Mixed procedure from SAS (Proc Mixed, Statistical Analysis System v. 8.2, Littell et al. 1996) to analyse NDVI, PMR and PUE data from different physiognomic classes. The mixed procedure allows modelling not only the data mean values but also its variance and co-variance (correlation). We evaluated numerous covariance structures using the Schwartz criteria (Schwartz 1978) and finally selected a compound symmetry structure for the spatial correlation and an autoregressive covariance structure for the temporal correlation. These structures were also used by Huenneke et al. (2002). Compound symmetry structure assumes that single site observations are correlated but are temporally independent while the autoregressive assumes that a given observation is more tightly correlated to the closest temporal observation. We used $F$-tests contrasts to test whether the differences between the response variable mean values were significantly different among physiognomic classes, and herbivore consumption categories. In every contrast $P$ values were adjusted using Sidak's (1967) method.

\section{Results}

\section{NDVI TEMPORAL DYNAMICS}

During the 5-year period, grass steppes and grass-shrub steppes, the physiognomic classes belonging to the least degraded status [state 1 in the Paruelo (2005) state and transition model], had the highest average NDVI: 0.37 and 0.35 , respectively (Fig. 3). NDVI from low cover grass steppes (a degraded state of grass steppes) equalled 0.28 , while for the classes corresponding to the most degraded state (state 3, i.e. shrub steppes and semi-deserts) NDVI was 0.25 and 0.23 , respectively. The results thus show that in this region the structural alteration of vegetation associated with desertification resulted in a decrease of about $28 \%$ in intercepted radiation. These values ranged between $22 \%$ (grass or grass-shrub steppes to low cover grass steppes) and 35\% (grass or grassshrub steppes to semi-deserts).

\section{DESERTIFICATION EFFECTS ON PMR AND PUE}

PMR and PUE captured the functional modifications associated with vegetation structure caused by desertification (Fig. 4). In general, grass and grass-shrub steppes, typical of a null or lightly degraded state, had the highest average values of PUE and PMR, with the exception of the low cover grass steppes whose PMR did not differ from that of the grass and grass-shrub steppes $(P=0 \cdot 13, n=1971$ and $P=0 \cdot 81$, $n=1971$, respectively). Shrub steppes and semi-deserts had the lowest PMR and PUE again with the exception of PMR of semi-deserts which was not significantly different from grass 


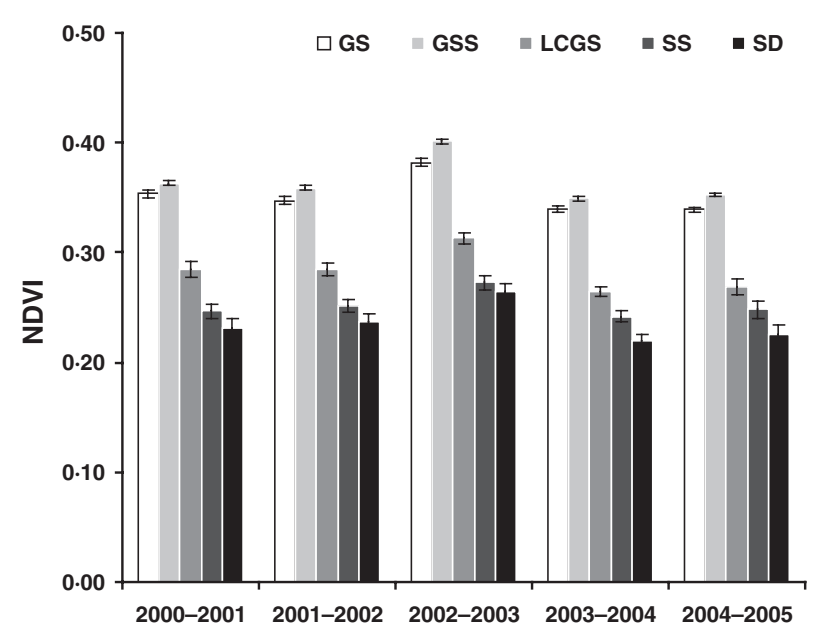

Fig. 3. NDVI time series per physiognomic class from 2000 to 2005. Bars indicate mean NDVI per growing season \pm spatial standard error. GS: grass steppes, GSS: grass-shrub steppes, LCGS: low cover grass steppes, SS: shrub steppes and SD: semi-deserts.
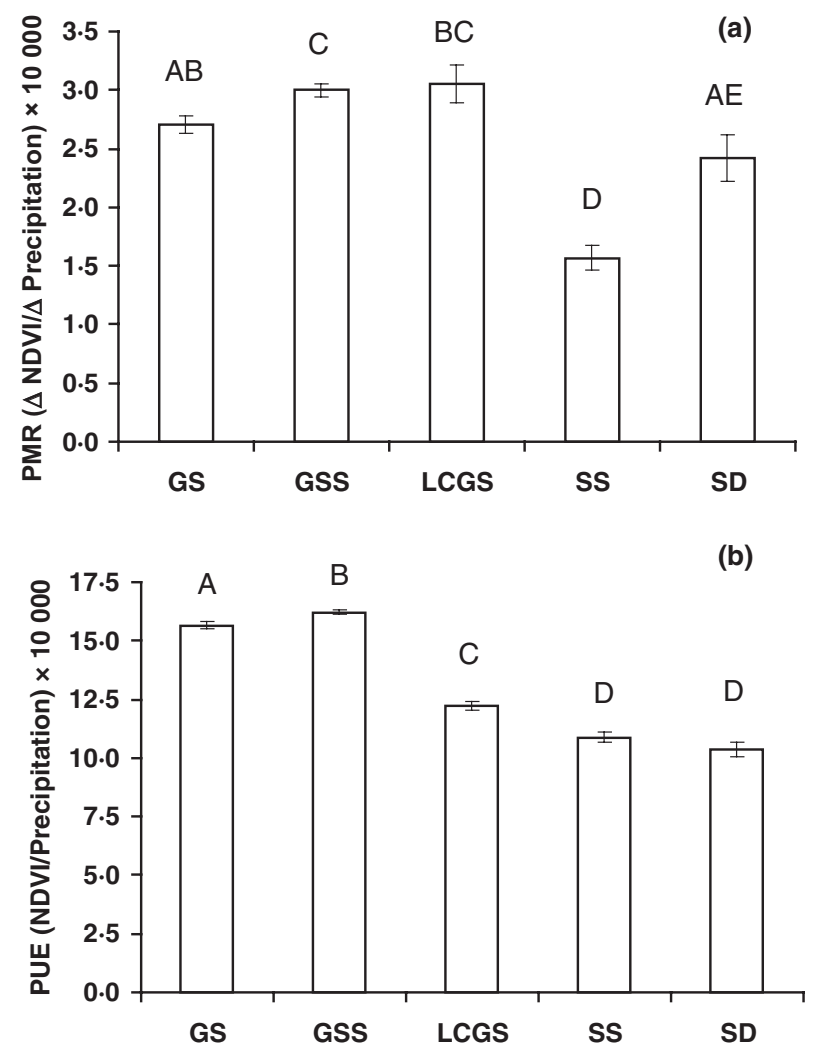

Fig. 4. PMR (a) and PUE (b) per physiognomic class. Bars indicate mean \pm spatial standard error. GS: grass steppes, GSS: grass-shrub steppes, LCGS: low cover grass steppes, SS: shrub steppes and SD: semi-deserts. PMR and PUE values were multiplied by 10000 . Capital letters indicate significant differences $(P<0.05)$ according to the linear mixed model applied.

steppes' PMR $(P=0 \cdot 17, n=1971)$. The PUE of shrub steppes and semi-deserts were not significantly different $(P=0 \cdot 29, n=1971)$.
If physiognomic types were grouped into an herbaceoustype (i.e. grass steppes, grass-shrub steppes and low cover grass steppes), a shrub-type (i.e. shrub steppes) and a semi-desert type, the differences in PMR appear to be more consistent than in PUE. For example, the differences between shrub steppes and semi-desert were more noticeable when compared in terms of PMR than of PUE (shrub steppes' PMR was 54.4\% lower than semi-desert, while for PUE the difference was only $4 \cdot 6 \%$ ). Additionally, the average PMR of herbaceous-type vegetation was higher than that of semi-deserts and shrub steppes, although this was not true when grass steppes were compared to semi-deserts. In turn, PUE was not as different as PMR among these physiognomic types. For example the PUE of shrub steppes and semi-desert was not significantly different while, within herbaceous-type vegetation, PUE displayed more variation than PMR (CV 14 vs. 6\% for PUE and PMR, respectively). Lastly, in contrast to PMR, low cover grass steppes had PUE values significantly different from any other physiognomic class. These were more similar to shrub steppes than to grass or grass-shrub steppes (Fig. 4).

\section{Discussion}

This is one of the few desertification studies that account for a reference situation. Herein, we show that the PMR and PUE differ among states of vegetation degradation. The reduction in PMR was most notable when desertification implied a physiognomic change while the most important reductions in PUE were observed between degraded situations of the same physiognomy. Our findings from NDVI data suggest that desertification in the Sub-Andean district of Patagonia implies a significant ANPP reduction.

\section{EFFECTS OF DEGRADATION ON NDVI}

The results found here show that desertification alters the proportion of photosynthetic active radiation intercepted by vegetation. During the growing season, the physiognomic classes corresponding to the most degraded states intercepted ca. onethird less radiation than their non-degraded counterparts. The magnitude of the effect implies alterations in the ANPP of the affected ecosystems. A reduction in interception (estimated by the NDVI) may translate into an amplified, damped or proportional reduction in the system's primary productivity depending on the change in radiation use efficiency (i.e. the quotient between net ANPP and intercepted radiation). At a global scale, Ruimy, Dedieu \& Saugier (1994) showed that the radiation use efficiency from Mediterranean shrublands was $55 \%$ less than that of temperate grasslands $\left(0 \cdot 32 \mathrm{~g} \mathrm{MJ}^{-1}\right.$ vs. $0 \cdot 84 \mathrm{~g} \mathrm{MJ}^{-1}$ ) while Potter et al. (1993), by means of simulation models, calculated a perennial grassland radiation use efficiency of $0.229 \mathrm{~g} \mathrm{C} \mathrm{MJ}^{-1}$ and of $0.208 \mathrm{~g} \mathrm{C} \mathrm{MJ}^{-1}$ for shrublands without a herbaceous layer. When the herbaceous layer was present, radiation use efficiency increased to $0.299 \mathrm{~g} \mathrm{C} \mathrm{MJ}^{-1}$, even higher than that for perennial grasslands. Considering these radiation use efficiency values, the replacement of grass steppes by semi-deserts would gener- 
ate a reduction in net primary production of roughly $75 \%$ or $42 \%$ depending on radiation use efficiency values documented by Ruimy, Dedieu \& Saugier (1994) or Potter et al. (1993), respectively. For an area that includes the one studied here, Paruelo et al. (2004) showed that ANPP (estimated from biomass harvests) was approximately three times higher for grass steppes than for semi-deserts. In turn, Aguiar et al. (1996), using simulation models, calculated that the replacement of the Festuca pallescens grassland characteristic of the Sub-Andean district by Mulinum spinosum shrublands would result in an ANPP reduction of $43 \%$. According to these authors the ANPP diminution would be a consequence of the inability of shrubs to use water freed by the removal of grasses. Altogether, the results found in this study and in the literature suggest that desertification in the Sub-Andean district of Patagonian may imply a reduction in ANPP. This is similar to that reported for South-African ecosystems (Wessels et al. 2004).

We can hypothesize that the phenological differences between shrubs and grasses and in its root vertical distribution may be responsible for the ANPP reduction in Patagonia. Shrubs from Patagonia typically concentrate most of their roots below the upper $30 \mathrm{~cm}$ (Fernández \& Paruelo 1988) while grass roots mainly explore the most superficial soil layers (Soriano, Golluscio \& Satorre 1987). In the grass-shrub steppes of Patagonia, the removal of grasses was associated with an increase in soil water potential along the first $60 \mathrm{~cm}$ while shrub removal did not generate significant changes (Sala et al. 1989). Therefore, the higher superficial soil water content would be subject to evaporation given that shrubs apparently do not display superficial roots. In the semi-deserts, where cushion-like species (i.e. Azorella monantha, Brachyclados lycioides, Acaena splendens) do concentrate their roots near to the surface, the lack of leaf area would hinder the efficient use of this resource. Moreover, this limited ability of Patagonian shrubs to use small to medium precipitation events and the reduction in radiation use efficiency would be responsible for the reduction in intercepted radiation in shrub steppes compared to the grass or grass-shrub steppes. On the contrary, the differential use of soil water by Patagonian shrubs and grasses may explain the higher PMR and PUE of the grass-shrub steppes compared to grass steppes. While grasses would use water accumulated in the soil superficial layers and small to medium rainfall events during the growing season, shrubs would benefit from water stored deep in the soil profile product of winter precipitation.

\section{CHANGES IN PMR AND PUE}

PUE, as PMR, differed among physiognomic classes representative of various degradation states associated to desertification (Fig. 4). In general, physiognomic classes belonging to the most degraded states (semi-desert and shrub steppes) had significantly lower PUE and PMR values than those lightly or non-degraded states (grass steppes or grass-shrub steppes). These observations support the hypothesis that desertification alters the response of vegetation to interannual changes in precipitation. Moreover, comparisons between PUE and PMR of certain physiognomic classes suggest that the information provided by both variables is not redundant. For example, PMR from low cover grass steppes, an intermediate degradation state from grass steppes, was not significantly different from the PMR of grass or grass-shrub steppes, while PUE was significantly lower. Similarly, shrub steppes and semi-desert displayed significant differences when compared in terms of PMR but not in terms of PUE. Reductions in plant cover between grass or grass-shrub and low cover grass steppes seem to be accompanied by a change in PUE. In drylands lower plant cover frequently has been associated with increases in bare soil evaporation, runoff, soil erosion, nutrient loss and harsher micro-meteorological conditions for the remaining plants (Fuls 1992) leading to a reduction in the resources effectively available to the vegetation. Also, the alternative strategy used by shrubs (deep rooting, tolerance to drought, lower foliar dynamism) relative to herbaceous vegetation (shallow rooting, intolerance to drought, higher foliar dynamisms) (Jauffret \& Visser 2003) may dictate changes in PMR. The ability of the vegetation to respond to interannual resource variations would reflect the trade-offs in adaptations to stress versus the ability to quickly make use of free resources. In conclusion, PMR seems to be more influenced by the physiognomy of vegetation whereas PUE is influenced by the amount of resources used.

Our findings related to the PMR confirm previous results at regional scales (Webb et al. 1978; Milchunas \& Lauenroth 1993; Paruelo \& Lauenroth 1995) or from simulation models (Reynolds et al. 2004; Paruelo et al. 2008). Paruelo \& Lauenroth (1995) showed that the slope of the relationship between mean annual NDVI and mean annual precipitation for 49 sites along a precipitation gradient from arid, semi-arid and temperate humid areas was lower for shrublands than for grasslands. Milchunas \& Lauenroth (1993) found that the slope of the ANPP and mean annual precipitation was 39\% less in shrubland sites than in grasslands and Webb et al. (1978) found similar patterns for ANPP and evapotranspiration. In turn, modelling studies conducted by Paruelo et al. (2008) showed that Festuca pallescens grasslands' PUE and PMR were negatively associated with grazing. These authors highlighted the decrease in tussock numbers as the main factor responsible for the reduction in PUE and PMR.

Although other factors such as the magnitude of precipitation events, antecedent soil water content, soil nitrogen availability, plant age, edaphic characteristics and resource heterogeneity (Reynolds et al. 2004) can certainly modify annual ANPP, it does not necessarily invalidate the use of PMR. In desertification studies the importance of single year ANPP estimations is downplayed as it is expected that desertification impacts will occur over longer periods. Thus, independently of annual ANPP estimation accuracy, PMR provides information about the system as it integrates the response of ANPP to precipitation from many years. Furthermore, it is expected that anomalies will compensate when longer periods are considered. The results found here suggest that for the SubAndean district of Patagonia a 5-year period is enough to find 
a consistent pattern in the response to interannual changes in water availability from vegetation physiognomies associated with a desertification gradient. Additionally, given that a single coarse physiognomic class may represent different degradation states (e.g. grass steppes and low cover grass steppes) or that different physiognomies may use the same amount of resources (e.g. grasslands and shrublands in Jornada) neither PUE nor PMR would suffice alone to identify and quantify the impact of desertification. The use of remote sensing estimates of PMR together with PUE (despite the uncertainty in the NDVI ANPP relationship) could therefore contribute to a better characterization of the impacts of human activities in drylands and to improve our predictions of ecosystems' response to climate change. The use of more mechanistic models to calculate ANPP from spectral indices (i.e. Monteith model, Running et al. 2000), would significantly increase the accuracy of the estimates (Piñeiro, Oesterheld \& Paruelo 2006).

\section{Acknowledgements}

This work was supported on grants from CONICET (SRV) and financial support provided by UBA, CONICET and FONCYT. Martin Oesterheld made valuable comments and suggestions that improved our manuscript. Julián Gonzalo from Rio Pico Grazing Company facilitated precipitation data and Compañia de Tierras Tecka S.A. - particularly Federico Ochoa and Carlos Moralejo - provided grazing data and critical facilities. SRV thanks especially to Irene Fabricante, Germán Baldi, Roxana Aragón, Fernando Biganzoli, Gonzalo Irisarri, Mariano Oyarzábal and Pablo Cipriotti for their invaluable help and support.

\section{References}

Aguiar, M.R., Paruelo, J.M., Sala, O.E. \& Lauenroth, W.K. (1996) Ecosystems responses to changes in plant functional type composition: an example from the patagonian steppe. Journal of Vegetation Science, 7, 381-390.

Akinremi, O.O., McGinn, S.M. \& Cutforth, H.W. (1999) Precipitation trends in the canadian prairies. Journal of Climate, 12, 2996-3003.

Bertiller, M.B. (1996) Grazing effects on sustainable semiarid rangelands in Patagonia: the state and dynamics of the soil seed bank. Environmental Management, 20, 123-132.

Bertiller, M. \& Bisigato, A. (1998) Vegetation dynamics under grazing disturbance. The state-and-transition model for the Patagonian steppes. Ecología Austral, 8, 191-200.

Bertiller, M.B., Elissalde, N.O., Rostagno, C.M. \& Deffosé, G.E. (1995) Environmental patterns and plant distribution along a precipitation gradient in western Patagonia. Journal of Arid Environments, 29, 85-97.

Diouf, A. \& Lambin, E.F. (2001) Monitoring land-cover changes in semi-arid regions: remote sensing and field observations in the Ferlo, Senegal. Journal of Arid Environments, 48, 129-148.

Fabricante, I., Oesterheld, M. \& Paruelo, J.M. (2009) Annual and seasonal variation of NDVI explained by current and previous precipitation across Northern Patagonia. Journal of Arid Environments, 73, 745-753.

Fernández, R.J. \& Paruelo, J.M. (1988) Root systems of two Patagonian shrubs: a quantitative description using a geometrical method. Journal of Range Management, 41, 220-223.

Fuls, E.R. (1992) Ecosystem modification created by patch-overgrazing in semi-arid grassland. Journal of Arid Environments, 23, 59-69.

Golluscio, R.A., León, R.J.C. \& Perelman, S. (1982) Caracterización de la estepa del oeste de Chubut; su relación con el gradiente ambiental. Boletín de la Sociedad Argentina de Botánica, 21, 299-324.

Hanafi, A. \& Jauffret, S. (2008) Are long-term vegetation dynamics useful in monitoring and assessing desertification processes in the arid steppe, southern Tunisia. Journal of Arid Environments, 72, 557-572.

Hein, L. \& de Ridder, N. (2006) Desertification in the Sahel: a reinterpretation. Global Change Biology, 12, 751-758.

Hill, J., Megier, J. \& Mehl, W. (1995) Land degradation, soil erosion and desertification monitoring in Mediterranean ecosystems. Remote Sensing Reviews, 12, 107-130.
Holm, A.M., Cridland, S.W. \& Roderick, M.L. (2003) The use of time-integrated NOAA NDVI data and rainfall to assess landscape degradation in the arid shrubland of western Australia. Remote Sensing of Environment, 85, $145-158$.

Huenneke, L.F., Anderson, J.P., Remmenga, M. \& Schlesinger, W.H. (2002) Desertification alters patterns of above ground net primary production in Chihuahuan ecosystems. Global Change Biology, 8, 247-264.

Huete, A., Didan, K., Miura, T., Rodriguez, E.P., Gao, X. \& Ferreira, L.G. (2002) Overview of the radiometric and biophysical performance of the MODIS vegetation indices. Remote Sensing of Environment, 83, 195-213.

Jauffret, S. \& Visser, M. (2003) Assigning life-history traits to plant species to better qualify arid land degradation in Presaharian Tunisia. Journal of Arid Environments, 55, 1-28.

Jobbágy, E.G., Sala, O.E. \& Paruelo, J.M. (2002) Patterns and controls of primary production in the Patagonian steppe: a remote sensing approach. Ecology, 83, 307-319.

Le Houérou, H.N (1984) Rain use-efficiency: a unifying concept in arid-land ecology. Journal of Arid Environments, 7, 213-247.

León, R.J.C. \& Aguiar, M.R. (1985) El deterioro por uso pasturil en estepas herbáceas patagonicas. Phytocoenologia, 13, 181-196.

León, R.J.C, Bran, D., Collantes, M., Paruelo, J.M. \& Soriano, A. (1998) Grandes unidades de vegetación de la Patagonia. Ecología Austral, 8, 125144

Littell, R.C, Milliken, G.A., Stroup, W.W. \& Wolfinger, R.D. (1996) $S A S^{\circledR}$ System for Mixed Models. SAS Institute Inc., Cary, NC.

Maestre, F.T. \& Escudero, A. (2009) Is the patch size distribution of vegetation a suitable indicator of desertification processes? Ecology, 90, 1729-1735.

McNaughton, S.J., Oesterheld, M., Frank, D.A. \& Williams, K.J. (1989) Ecosystem-level patterns of primary productivity and herbivory in terrestrial habitats. Nature, 341, 142-144.

Milchunas, D.G. \& Lauenroth, W.K. (1993) A quantitative assessment of the effects of grazing on vegetation and soils over a global range of environments. Ecological Monographs, 63, 327-366.

Nicholson, S.E., Tucker, C.J. \& Ba, M.B. (1998) Desertification, drought and surface vegetation: an example from the West African Sahel. Bulletin of the American Meteorological Society, 79, 815-829.

Noy-Meir, I. (1973) Desert ecosystems: environment and producers. Annual Review of Ecology and Systematics, 4, 25-51.

O'Connor, T.G., Haines, L.M. \& Snyman, H.A. (2001) Influence of precipitation and species composition on phytomass of semi-arid African grassland. Journal of Ecology, 89, 850-861.

Paruelo, J.M (2005) Cuánto se han desertificado las estepas patagónicas? Evidencias a partir de la memoria del sistema. La Heterogeneidad de la Vegetación de los Agroecosistemas. Un Homenaje a ROLANDO León (eds M. Oesterheld, M.R. Aguiar, C.M. Ghersa \& J.M. Paruelo), pp. 303-319. Facultad de Agronomía, UBA, Buenos Aires.

Paruelo, J.M. \& Bertiller, M.B. (1993) Secuencias de Deterioro en Distintos Ambientes Patagónicos. Su Caracterización Mediante el Modelo de Estados y Transiciones. Convenio Argentino -Alemán, Cooperación Técnica INTAGTZ.

Paruelo, J.M., Jobbagy, E.G. \& Sala, O.E. (1998) Biozones of patagonia (Argentina). Ecología Austral, 8, 145-153.

Paruelo, J.M. \& Lauenroth, W.K. (1995) Regional patterns of NDVI in North American shrublands and grasslands. Ecology, 76, 1888-1898.

Paruelo, J.M. \& Sala, O.E. (1995) Water losses in the Patagonian steppe: a modeling approach. Ecology, 76, 510-520.

Paruelo, J.M., Sala, O.E. \& Beltrán, A.B. (2000) Long-term dynamics of water and carbon in semi-arid ecosystems: a gradient analysis in the Patagonian steppe. Plant Ecology, 150, 133-143.

Paruelo, J.M., Golluscio, R.A., Guerschman, J.P., Cesa, A., Jouve, V. \& Garbulsky, M.F. (2004) Regional scale relationships between ecosystem structure and functioning. The case of the patagonian steppes. Global Ecology and Biogeography, 13, 385-395.

Paruelo, J.M., Pütz, S., Weber, G., Bertiller, M.B., Golluscio, R.A., Aguiar, M.R. \& Wiegand, T. (2008) Long-term dynamics of a semiarid grass steppe under stochastic climate and different grazing regimes: a simulation analysis. Journal of Arid Environments, 72, 2211-2231.

Piñeiro, G., Oesterheld, M. \& Paruelo, J.M. (2006) Seasonal variation in aboveground production and radiation use efficiency of temperate rangelands estimated through remote sensing. Ecosystems, 9, 357-373.

Potter, C.S., Randerson, J.T., Field, C.B., Matson, P.A., Vitousek, P.M., Mooney, H.A. \& Klooster, S.A. (1993) Terrestrial ecosystem production: a process model based on global satellite and surface data. Global Biogeochemical Cycles, 7, 811-841. 
Prince, S.D., Brown de Colstoun, E. \& Kravitz, L.L. (1998) Evidence from rain-use efficiencies does not indicate extensive sahelian desertification. Global Change Biology, 4, 359-374.

Prince, S.D., Wessels, K.J., Tucker, C.J. \& Nicholson, S.E. (2007) Desertification in the Sahel: a reinterpretation of a reinterpretation. Global Change Biology, 13, 1308-1313.

Reynolds, J.F. (2001) Desertification. Encyclopedia of Biodiversity (ed. S. Levin), pp. 61-78. Academic Press, San Diego.

Reynolds, J.F., Kemp, P.R., Ogle, K. \& Fernández, R.J. (2004) Modifying the "pulse-reserve" paradigm for deserts of North America: precipitation pulses, soil water, and plant responses. Oecologia, 141, 194-210.

Ruimy, A., Dedieu, G. \& Saugier, B. (1994) Methodology for the estimation of terrestrial net primary production from remotely sensed data. Journal of Geophysical Research, 99, 5263-5284.

Running, S.W., Thorton, P.E., Nemani, R.R. \& Glassy, J.M. (2000) Global terrestrial gross and net primary productivity from the earth observing system. Methods in Ecosystem Science (eds O.E. Sala, R.B. Jackson, H.A. Mooney \& R.W. Howarth), pp. 44-57. Springer, Berlin/Heidelberg/New York.

Sala, O.E., Golluscio, R.A., Lauenroth, W.K. \& Soriano, A. (1989) Resource partitioning between shrubs and grassess in the Patagonian steppe. Oecologia, 81, 501-505.

Schlesinger, W.H., Reynolds, J.F., Cunningham, G.L., Huenneke, L.F., Jerrell, W.M., Virginia, R.A. \& Whitford, W.G. (1990) Biological feedbacks in global desertification. Science, 247, 1043-1048.

Schwartz, G. (1978) Estimating the dimension of a model. Annals of Statistics, 6, 461-464.

Scurlock, J.M.O., Johnson, K. \& Olson, R.J. (2002) Estimating net primary productivity from grassland biomass dynamics measurements. Global Change Biology, 8, 736-753.

Sellers, P.J., Berry, J.A., Callatz, G.J., Field, C.B. \& Hall, H.G. (1992) Canopy reflectance, photosynthesis, and transpiration. III. A reanalysis using improved leaf models and a new canopy integration scheme. Remote Sensing of Environment, 42, 187-216.

Sharma, K.D. (1998) The hydrological indicators of desertification. Journal of Arid Environments, 39, 121-132.

Sidak, Z. (1967) Rectangular confidence regions for the means of multivariate normal distributions. Journal of the American Statistical Association, 62 626-633.

Soriano, A. (1956) Los distritos florísticos de la provincia Patagónica. Revista de Investigaciones Agropecuarias, 10, 323-347.

Soriano, A., Golluscio, R.A. \& Satorre, E.H. (1987) Spatial heterogeneity of the root systems of grasses in the patagonian arid steppe. Bulletin of the Torrey Botanical Club, 114, 103-108.

Soriano, A. \& Movia, C.P. (1986) Erosión y desertización en Patagonia. Interciencia, 11, 77-83.
Soriano, A. \& Paruelo, J.M. (1990) El manejo de campos de pastoreo en Patagonia: aplicación de principios ecológicos. Ciencia Hoy, 2, 44-53.

Verón, S.R., Oesterheld, M. \& Paruelo, J.M. (2005) Production as a function of resource availability: slopes and efficiencies are different. Journal of Vegetation Science, 16, 351-354.

Verón, S.R., Paruelo, J.M. \& Oesterheld, M. (2006) Assessing Desertification. Journal of Arid Environments, 66, 751-763.

Viovy, N., Arino, O. \& Belward, A.S. (1992) The best index slope extraction (BISE): a method for reducing noise in NDVI time-series. International Journal of Remote Sensing, 13, 1585-1590.

Webb, W., Szarek, S., Lauenroth, W.K., Kinerson, R. \& Smith, M. (1978) Primary productivity and water use in native forest, grassland and desert ecosystems. Ecology, 59, 1239-1247.

Wessels, K.J., Prince, S.D., Frost, P.E. \& van Zyl, D. (2004) Assessing the effects of human-induced degradation in the former homelands of northern South Africa with a $1 \mathrm{~km}$ AVHRR NDVI time-series. Remote Sensing of Environment, 91, 47-67.

Wessels, K.J., Prince, S.D., Malherbe, J., Small, J., Frost, P.E. \& VanZyl, D. (2007) Can human-induced land degradation be distinguished from the effects of rainfall variability? A case study in South Africa Journal of Arid Environments, 68, 271-297.

Received 11 March 2010; accepted 25 August 2010

Handling Editor: Richard Wadsworth

\section{Supporting Information}

Additional Supporting Information may be found in the online version of this article:

Appendix S1. Identification of the reference situation.

Fig. S1. Geologic map of the northern part of the study area.

Fig. S2. Limits of the study area and location where the 39 floristic releves were conducted.

As a service to our authors and readers, this journal provides supporting information supplied by the authors. Such materials may be re-organized for online delivery, but are not copy-edited or typeset. Technical support issues arising from supporting information (other than missing files) should be addressed to the authors. 